SCJR 16, no. 1 (2021): 1-3

\title{
Christian Danz, Kathy Ehrensperger, and Walter Homolka (Eds.) Christologie Zwischen Judentum und Christentum
}

(Tübingen: Mohr Siebeck 2020), xiv + 447 pp.

GREGOR MARIA HOFF

gregor.hoff@sbg.ac.at

University of Salzburg, Salzburg, Austria

In recent years, the discussion about the significance of Christology in JewishChristian dialogue has taken on a new dynamic. Various factors are responsible for this. Two recent documents by Orthodox Jews, "To Do the Will of Our Father in Heaven" (2015) and "Between Jerusalem and Rome" (2016), represent important statements. The authors raise essential questions about Christology. Among them is the question of how Jewish-Christian dialogue can deal with the issue. For the Catholic Church, more than fifty years after the conclusion of the Second Vatican Council, a theological deepening of the basis for dialogue is on the agenda in its contact with Judaism. With the document "“The Gifts and the Calling of God Are Irrevocable"" (2015), the Vatican Commission for Religious Relations with the Jews once again raised the question of the significance of the "universality of salvation in Jesus Christ" (Sect. 37) and affirmed that the "covenant of God with Israel has never been revoked" (Preface). In addition to the issues raised by these religious communities, there have been shifts in various theological discourses. They concern exegetical perspectives which, starting from the New Perspective on Paul, also concern Christological questions. They are connected with questions about the "parting of the ways" and the complex emergence of rabbinic Judaism and Christianity. They concern tradition-historical questions about the development of theological concepts in both traditions and in relations between them, revealing their inner diversity. In this context, the historical Jesus and the Christ of faith are the subject of a new discussion. This discussion has been shaped by an awareness of Jesus' Jewishness and raises methodological-hermeneutical questions about how to think about him.

These questions come to a head when considering Jesus' theological significance, which on the one hand sets a marker of difference between Judaism and Christianity, but on the other hand also can problematize the self-understanding in the two religions. In recent years, Walter Homolka in particular has recalled the 
history of Jewish research on Jesus in order to make it productive for a Jewish perception of Jesus. His Jesus Reclaimed: Jewish Perspectives on the Nazarene (2015) is a title that profiles the "Jewish Jesus" as "a challenge for Christian theology." Following up on this work, Homolka, together with the Catholic theologian Magnus Striet, published another volume, Christologie auf dem Prïfstand [Jesus the Jew - Christ the Redeemer] (2019). Questions are emerging that concern the significance of Christology for both Jewish and Christian theologies.

This discussion is influenced by the complex interconnection of academic discourses, each with its own methodological approaches and epistemological presuppositions (e.g., biblical exegesis and systematic theology). Also, questions about the placement of boundaries between Judaism and Christianity, unstated assumptions, and religious beliefs have an impact on Christology. Out of this complexity have emerged efforts to construct the figure of Jesus of Nazareth and to establish his theological significance.

This volume, which gathers together papers presented at a conference in Vienna in 2019, misses this discursive landscape. The essays, while of high quality, are primarily written by Protestant and Catholic theologians, though there are three by Jews (both liberal and Orthodox). This imbalance means there is little sense of inter-religious dialogue, though the Christian authors do refer to Jewish positions. Another peculiarity concerns the composition of the volume: it is not organized around disciplines or themes. Two introductory essays on the tradition of Jewish Jesus research (by Verena Lenzen and Walter Homolka) are followed by four exegetical analyses (by Markus Öhler, Martin Stowasser, Paula Fredriksen, and Kathy Ehrensperger). Next, there are fourteen essays from a systematic-theological perspective. The result is a rather loose sequence of essays, though the essays themselves exhibit a very dense interweaving of similar problems, methodological approaches, and argumentation. The reader is thus challenged to establish connections in order to map the project of a "Christology between Judaism and Christianity."

These connections emerge between historical-biblical and systematictheological approaches. The contributors, with their different methodological approaches, consider the significance of historical research for the "construction of Christology" (3). They raise the question of the plausibility of Christological models, and whether they are able to "elaborate or substantiate a lasting significance of Jewish religion within the framework of Christology" (3). In the course of the essays it becomes apparent that this question is connected with the ecclesiastical frameworks used to present diverse Christologies. While Paula Fredriksen, in her essay "Christus und das Reich Gottes. Oder Paulus, der Diasporajude, und der christliche Erlöser" (81-107), sees the early church councils as "transversal to Paul's very immediate eschatological Christ" (105), Josef Wohlmuth argues that the Council of Chalcedon illustrates a continuing influence of Jewish traditions in efforts to affirm both the human reality of Jesus Christ and the transcendence of God ("Der jüdische Jesus und die Christologie des Konzils von Chalkedon" [319-32, especially 326-28]). 
This raises a crucial question: Is Christology a dissociation from the Jewishness of Jesus by a church that ignores the religio-cultural context of the Nazarene and his movement? And what then does it mean to speak of the Holy Spirit not abstractly but in real terms, as identified with a real man (Jesus of Nazareth confessed as Christ)? Answers to these questions reflect confessional divergences which are not discussed as such but are reflected in the various texts.

They are linked to a decisive question: in what way and with what consequences does a Christology that recognizes Jesus as a Jew of his time challenge some traditional forms of theology, especially given the importance of Christology? For, in Christian Danz's words, "dogmatic Christology is not [just] a component of the content of the Christian religion, but a level of reflection within it" ("Christologie als Bestätigung der jüdischen Religion? Reflections on the Doctrine of Jesus Christ in the Age of Religious Pluralism" [123-44; 140]). This proposal, in turn, can meet with determined resistance within the Christian community because potentially threatens the specifically theological claim to validity of Christianity - for example, in its soteriological dimensions (as discussed in chapters by Christoph Schwöbel and Klaus von Stosch). Magnus Striet argues for the ethical dubiousness of a historical Christology grounded in a crucifixfocused theology and a view of redemption in which God sacrifices his Son. Striet insists on a Jewishly-grounded "ethical monotheism" which takes Jesus' message of freedom in the kingdom of God seriously ("Vom Judesein Jesu und einem notwendigen dogmatischen Umdenken" [311-18; 317]). These discussions all raise the question whether soteriology can ever be less prominent in Christian theology, though some contributors present a decidedly theocentric Christology (Erwin Dirscherl, Helmut Hoping, Heinz-Günther Schöttler).

New, creative Christologies can serve as models for dialogue between Jews and Christians. While they are still little known or developed, the authors in this volume begin to sketch the contours of what they may look like. It is important for there to be an underlying hermeneutic compatible with theological conceptions that accept differences in traditional portraits of God (especially chapters by Klaus von Stosch and Reinhold Bernhardt), and this volume, with its multiple contributors, reflects this diversity. As patristics scholar Christoph Markschies shows, for those with an affinity for plurality, the history of Christological thought in fact provides its own resources ("Die Erforschung antiker christologischer Reflexion und der jüdisch-christliche Dialog - ein Prospekt" [247-69]). His essay not only is a gem of subtle philology and fine theological judgement but, if read paradigmatically, also provides some overall direction in a volume that, with the high quality of its contributions, sets an inspiring point of reference for further Christological reflections between Judaism and Christianity. 